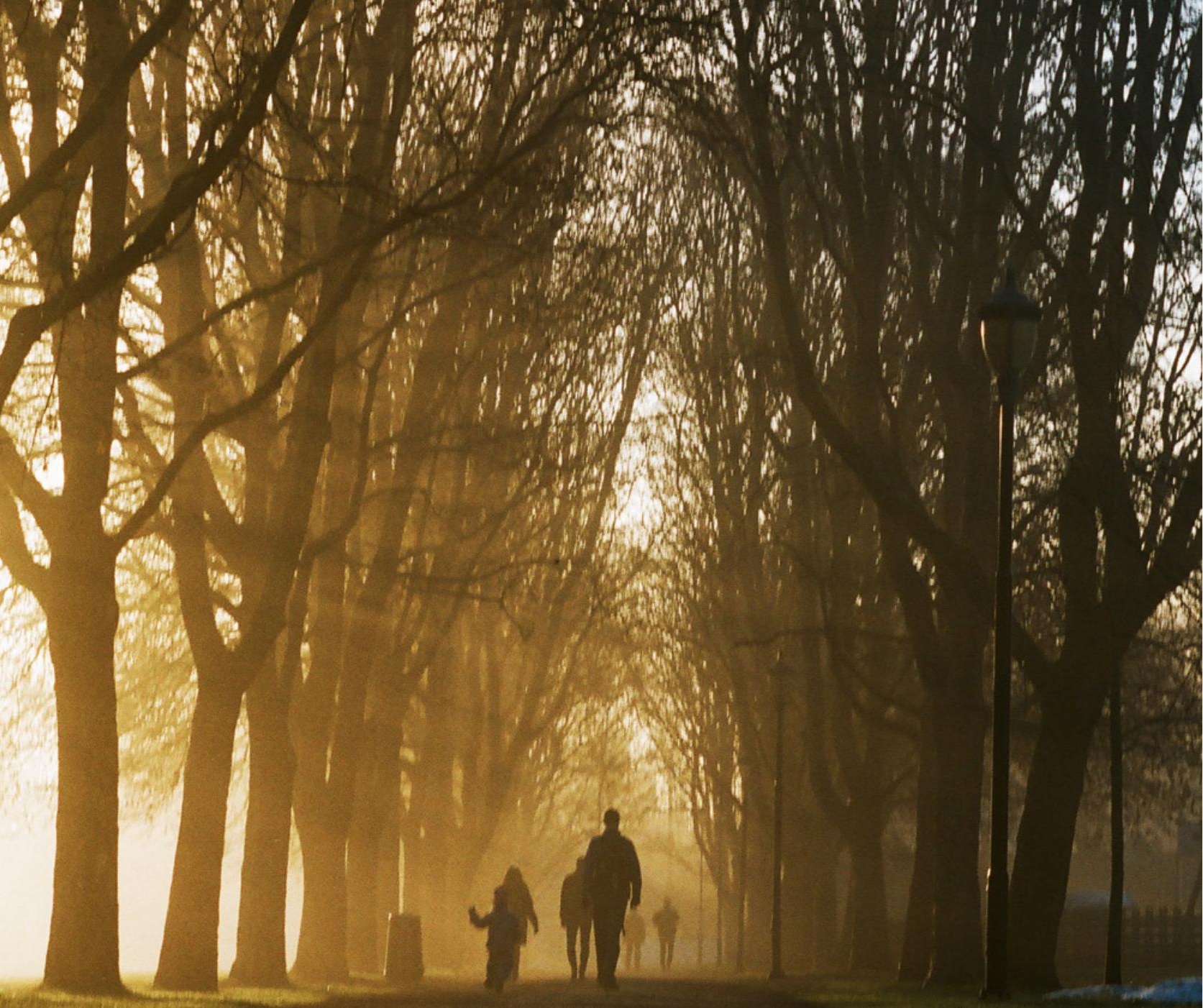




\section{Program for likestilling}

- Norges formannskap for Nordisk ministerråd 2017

ISBN 978-92-893-4880-5 (PRINT)

ISBN 978-92-893-4881-2 (PDF)

http://dx.doi.org/10.6027/ANP2017-716

ANP 2017:716

(c) Nordisk ministerråd 2017

Layout: Louise M. Jeppesen

Omslagsfoto: Unsplash.com

Trykk: 07-gruppen

Opplag: 500

Printed in Norway

\section{Det nordiske samarbeidet}

Det nordiske samarbeidet er en av verdens mest omfattende regionale samarbeidsformer.

Samarbeidet omfatter Danmark, Finland, Island, Norge og Sverige samt Færøyene, Grønland og Åland.

Det nordiske samarbeidet er både politisk, økonomisk og kulturelt forankret, og er en viktig medspiller i det europeiske og internasjonale samarbeidet. Det nordiske fellesskapet arbeider for et sterkt Norden i et sterkt Europa.

Det nordiske samarbeidet ønsker å styrke nordiske og regionale interesser og verdier i en global omverden. Felles verdier landene imellom er med på å styrke Nordens posisjon som en av verdens mest innovative og konkurransekraftige regioner.

\section{Nordisk ministerråd}

Ved Stranden 18

DK-1061 København K

www.norden.org

Download nordiske publikasjoner: www.norden.org/nordpub 


\section{PROGRAM FOR LIKESTILLING}

- Norges formannskap for Nordisk ministerråd 2017

INNHOLD

4 Forord av barne- og likestillingsminister Solveig Horne

6 Det nordiske likestillingssamarbeidet

7 Prioriterte tema og aktiviteter i 2017

16 Andre aktiviteter 2017

18 Kalender 
Forord av Solveig Horne Barne- og likestillingsminister

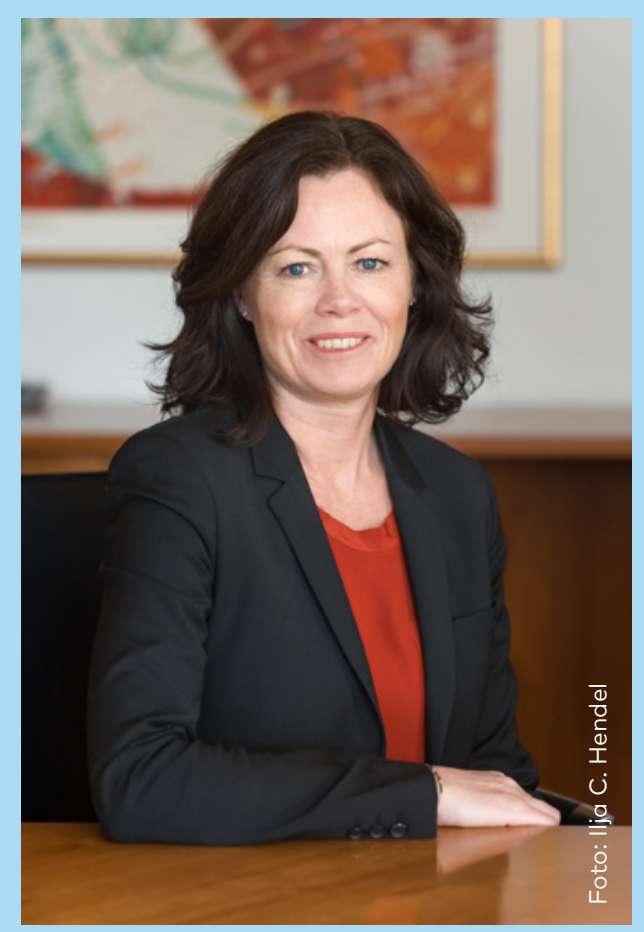


Norge leder det nordiske samarbeidet på likestillingsområdet i 2017. Vi har et viktig og godt naboskap der vi utveksler erfaringer og lærer av hverandre. I over 40 år har vi arbeidet med likestillingsutfordringer i felleskap. Likestilling mellom kvinner og menn er et kjennetegn ved de nordiske landene, og det er en forutsetning for gode liv for den enkelte og for bærekraftige velferdsstater.

Mine nordiske kollegaer og jeg har vedtatt samarbeidsprogrammet Tilsammans för jämställdhet - ett starkare Norden 2015-2018. Vi bygger videre på dette i vårt formannskap. Norge har fire hovedprioriteringer på likestillingsområdet i formannskapsåret 2017:

- Arbeid mot vold.

- Arbeidet mot hatefulle ytringer.

- $\quad$ Likestilling i arbeidslivet.

- Menn og likestilling.

For Norge går det nordiske samarbeidet hånd i hånd med arbeidet med likestilling på nasjonalt nivå. Regjeringens stortingsmeldinger om likestillingspolitikken og familiepolitikken legger føringer på arbeidet nasjonalt, men kan også ses i sammenheng med det nordiske samarbeidet. Norge lanserte høsten 2016 en strategi for arbeidet mot hatefulle ytringer som også inkluderer arbeidet på nordisk nivå. Arbeidet mot hatefulle ytringer er viktig i seg selv, og samarbeidet på tvers av Norden gir det en ekstra verdi.

Norden har en sterk stemme i likestillingsarbeidet internasjonalt. Det nordiske bidraget til jenter og kvinners stilling globalt er betydningsfull. I et eget initiativ lanserer statsministrene nordiske løsninger på globale utfordringer der høy deltakelse av både kvinner og menn $\mathrm{i}$ arbeidslivet står sentralt. Likestilling i arbeidslivet er hovedtema under FNs Kvinnekommisjon (CSW) i New York dette året. Vi har en ambisjon om at Nordens stemme skal bli enda tydeligere på CSW i 2017.

Norges hovedprogram for 2017 setter Norden på dagsorden, både lokalt, regionalt og globalt. Norden i omstilling, Norden i Europa og Norden i verden er pilarer for Norges hovedprogram hvor bærekraft og et styrket samarbeid lokalt, regionalt og globalt peker framover. Bærekraft forutsetter at jenter og gutter, menn og kvinner gis like muligheter til å delta. I 2017 bidrar likestillingsområdet med kunnskap, eksempler og samarbeid som bringer oss framover og styrker både enkeltmennesket og samfunnet. 


\section{Det nordisk likestillingssamarbeidet}

De nordiske landene, Færøyene, Grønland og Ålands samarbeid om likestillingsområdet drives av en felles, nordisk visjon om et likestilt Norden med like muligheter, rettigheter og plikter for alle innbyggere vansett om de er jenter eller gutter, menn eller kvinner. Samarbeidet ledes av de nordiske likestillingsministrene som utgjør ministerrådet for likestilling (MR-JÄM). Embetsmannskomiteen for likestilling (ÄK-JÄM), som består av representanter fra de nordiske landene og Færøyene, Grønland og Åland, leder det praktiske arbeidet og forbereder ministermøtene.

Formannskapet i Nordisk Ministerråd roterer mellom de fem nordiske landene og i 2017 har Norge formannskapet. Det er et mål for arbeidet på likestillingsfeltet at det skal være langsiktig og følge opp tidligere satsinger. De nordiske likestillingsministrene har besluttet at menn og gutters involvering i likestillingsarbeidet skal styrkes og dette vil
Norge følge opp. Satsingene på arbeidet mot vold og hatefulle ytringer følger opp Finlands satsing på vold i 2016 og ministerinitiativet om hatefulle ytringer som startet under Danmarks formannskap i 2015. Likestilling i arbeidslivet er et eget tema under formannskapsåret. Det er også tema for FNs Kvinnekommisjon i 2017 og i et eget initiativ tatt av de nordiske statsministrene om å tilby "nordiske løsninger på globale utfordringer". I 2019 planlegger Island å arrangere en nordisk konferanse i forbindelse med ILOs 100-årsjubileum i 2019 med samme tema.

NIKK - Nordisk informasjon for kunnskap om kjønn, er ministerrådet for likestilling sitt samarbeidsorgan. NIKK har som hovedoppgave, i et nordisk og tverrsektorielt perspektiv, å samle inn og formidle forskning, politikk, kunnskap og praksis på likestillingsområdet. NIKK skal også formidle og synliggjøre ministerro̊det for likestilling sin virksomhet. 


\section{Prioriterte tema og aktiviteter i 2017}

De nordiske likestillingsministrene vedtok i 2015 samarbeidsprogrammet for 2015-2018, "Tilsammans för jämställdhet - ett starkare Norden", som legger rammen for Norges formannskap i MRJÄM i 2017. Norges hovedprioriteringer på likestillingsområdet i formannskapsåret 2017 er:

- Arbeid mot vold.

- Arbeidet mot hatefulle ytringer.

- Likestilling i arbeidslivet.

- Menn og likestilling.

Det er et mål at arbeidet på likestillingsfeltet skal være langsiktig og følge opp tidligere satsinger. Frihet fra vold er et viktig mål, også innen det nordiske sam- arbeidet. Norge følger opp satsingene i 2016 med et prosjekt knyttet til landenes implementering av Istanbulkonvensjonen. I 2015 initierte Danmark en egen satsing mot sexisme og hatefulle ytringer. Norge følger opp dette, og arbeidet mot hatefulle ytringer er en viktig del av formannskapsarbeidet.

Arbeidet for likestilling i arbeidslivet under Norges formannskap i 2017 faller sammen med at likestilling i arbeidslivet er hovedtema for FNs Kvinnekommisjon i 2017. I tillegg peker de nordiske statsministrene på likestilt arbeidsliv som ett av tre områder hvor Norden kan tilby "nordiske løsninger på globale utfordringer". 


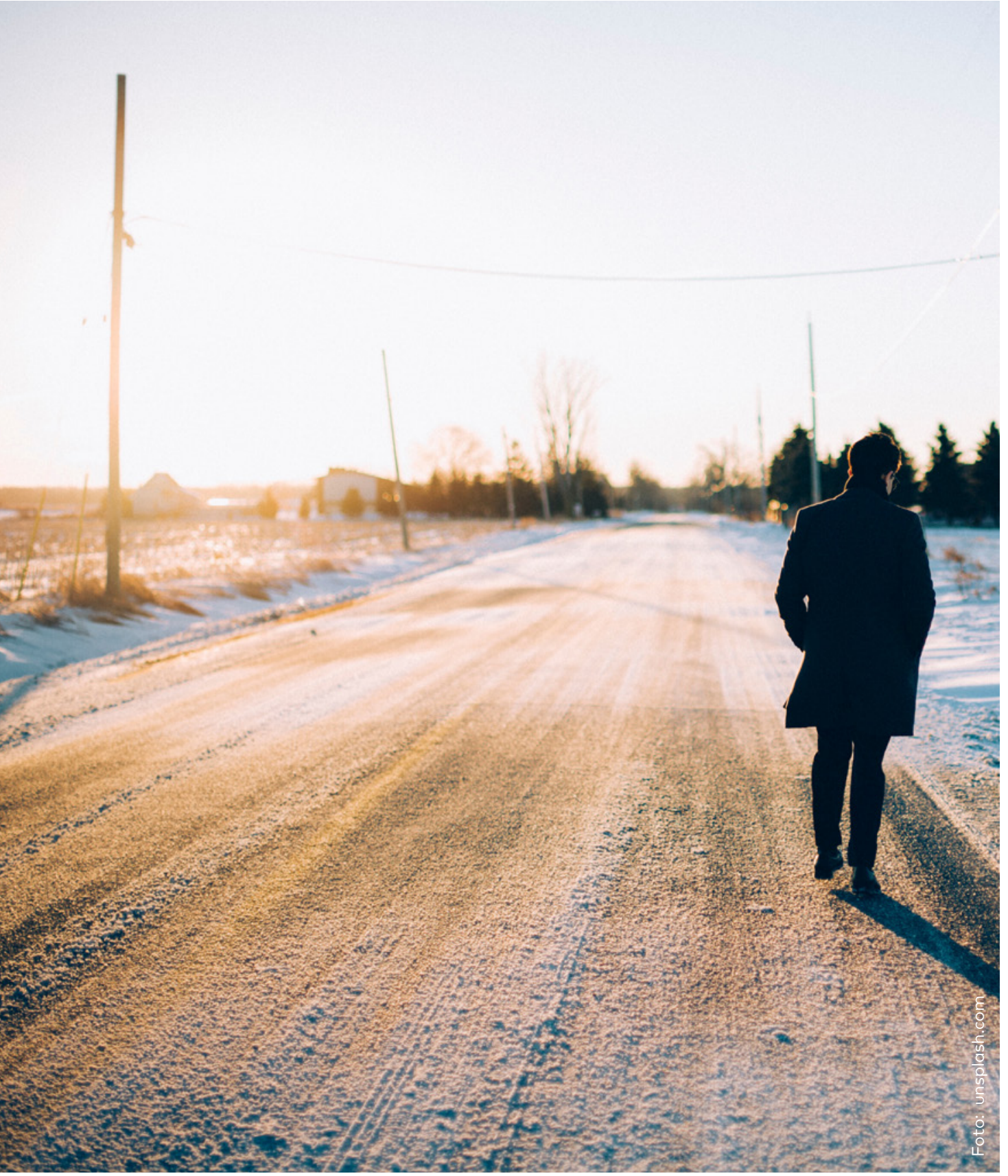




\section{ARBEIDET MOT VOLD}

Ministerrådet for likestilling har nulltoleranse for kjønnsbasert vold i Norden. Det er først og fremst kvinner som er ofre for den kjønnsbaserte volden, men vold i nære relasjoner berører også menn og barn. Rettighetene og hjelpetiltakene til ofrene har en sentral plass i bekjempelsen av kjønnsbasert vold. Tiltak rettet mot voldsutøvere for å forebygge vold er også viktige.

I juli 2011 ble Europarådets konvensjon om å forebygge og bekjempe vold mot kvinner og vold i nære relasjoner vedtatt. Konvensjonen, kalt Istanbulkonvensjonen, er underskrevet av alle de nordiske landene. Sverige, Danmark og Finland har ratifisert konvensjonen. Norge planlegger å ratifisere Istanbulkonvensjonen snarlig, og Island har ambisjon om å ratifisere konvensjonen i 2017. Konvensjonen har blant annet som målsetting å beskytte kvinner mot alle former for vold, og å forebygge, rettsforfølge og avskaffe alle former for vold mot kvinner og vold i nære relasjoner.

Implementering av Istanbulkonvensjonen Under Norges formannskap vil Barne- og likestillingsdepartementet samarbeide med Justis- og beredskapsdepartementet om å gjennomføre prosjektet De nordiske landenes implementering av Istanbulkonvensjonen. Prosjektet skal se på hvordan de nordiske landene implementerer et utvalg forpliktelser når det gjelder arbeidet for å forebygge vold i nære relasjoner i de nordiske land og hvilken beskyttelse og støtte som gis til utsatte for vold.

Formålet med prosjektet er å lære av hverandres arbeid, utvikle og forbedre innsatsen. Det er viktig å dele erfaringer med andre land i Europa. Arbeidet for å forebygge og bekjempe vold mot kvinner og vold i nære relasjoner har noe ulik innretning i de enkelte nordiske landene og potensialet for å overføre kunnskap og lære av hverandre er stort.

\section{Prosjektrapport og nordisk konferanse} 29.-30. november 2017 29.-30. november 2017 arrangerer Norge en felles nordisk konferanse der resultatene blir presentert og diskutert. Prosjektet skal resultere i en rapport som beskriver, sammenligner og analyserer de tiltakene som er iverksatt i de nordiske landene. 


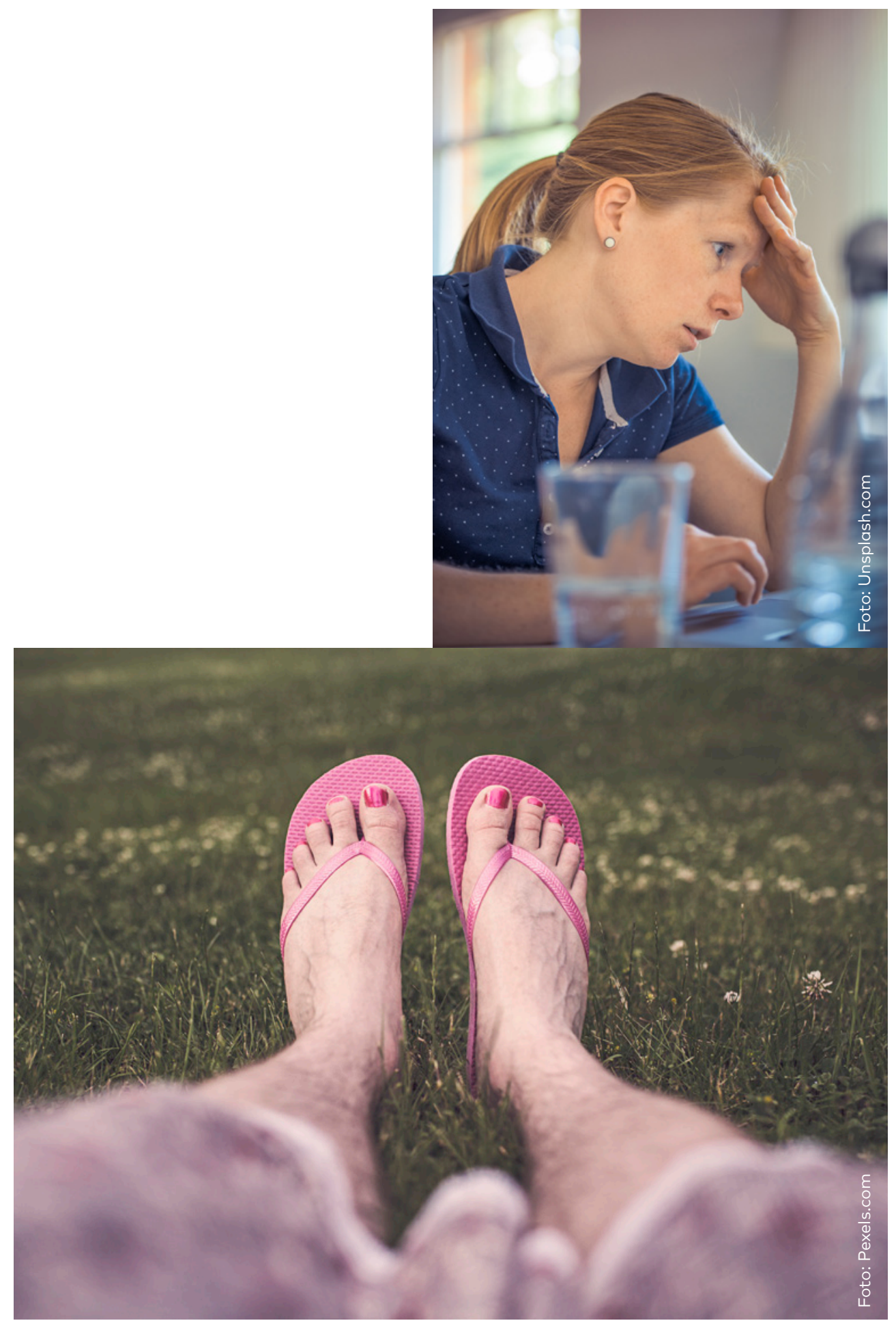




\section{ARBEIDET MOT KJØNNSBASERTE HATEFULLE YTRINGER}

De nordiske likestillingsministrene vedtok arbeidet mot kjønnsbaserte hatefull ytringer som en egen satsing for det nordiske samarbeidet i 2015 . Arbeidet mot hatefulle ytringer har som overordnet mål å forebygge og bekjempe hatefulle ytringer og konsekvenser av det i den offentlige debatten og i det offentlig rom. Det er et klart uttrykt mål at kvinner og menn i Norden skal ha like muligheter og lik tilgang til media og på like vilkår delta i det offentlige ordskiftet. Det er viktig å verne om ytringsfriheten. I et demokrati må vi tåle en skarpt formulert debatt, men veksten av hatefulle ytringer i for eksempel sosiale medier gjør at mange vegrer seg for å delta i den offentlige samtalen. Det gjør at debatten blir fattigere og det er et tap for demokratiet og den offentlige samtalen.

Forskning viser at menn i noe større grad enn kvinner utsettes for hat og trusler når de deltar i samfunnsdebatten på sosiale medier. Samtidig er det slik at hatytringer rettet mot kvinner i større grad er seksualisert hat som retter seg mot kjønn, seksualitet og utseende. Forskning viser at kvinner modifiserer, tilpasser, og endrer sin deltakelse i debatter på grunn av hatytringer i større grad enn menn. Det er med andre ord nødvendig å bekjempe alle typer hatefulle ytringer rettet mot både menn og kvinner, samtidig som vi ser på hvordan vi særlig kan sikre kvinner en likestilt plass i det offentlige ordskiftet.
Ministerinitiativet følges opp med en større fellesnordisk kartlegging som NIKK - Nordisk informasjon for kunnskap om kjønn, har ansvar for og som ferdigstilles våren 2017. Kartleggingen skal også munne ut i anbefalinger om hvordan vi kan motarbeide kjønnsbaserte hatefulle ytringer både med juridiske og politiske virkemidler.

Den nordiske kartleggingen skal følges opp med produksjon av en informasjonspakke på alle fem nordiske språk. Målgruppen er barn og unge i alderen 10-18 år. Arbeidet med å lage informasjonspakken er Norges ansvar. Arbeidet med informasjonsmateriellet skal forankres i Norges fagdirektorat, Barne-, ungdomsog familiedirektoratet, og arbeidet skal involvere Nordisk barne- og ungdomskomité. Det vil bli avgjørende å tilpasse materiellet til det enkelte nordiske land, og i den forbindelse bygge videre på allerede eksisterende arbeid.

Norge skal arrangere en større nordisk/ internasjonal konferanse om hatefulle ytringer 21.-22. juni 2017 i Stavanger. Formålet er å presentere kunnskap om temaet og erfaringer fra arbeid mot hatefulle ytringer. Målgruppen er praktikere, ungdom, sivil samfunn, myndigheter, forskere, eksperter, med mer. 
I Norge er det åtte store

arbeidslivsorganisasjoner som alle deltar i trepartssamarbeidet med norske myndigheter. Kan det være en aldri så liten verdensrekord at ved årsskiftet 2016-2017 er alle disse hovedorganisasjonene ledet av kvinner? Her er kanskje de to mektigste av dem, administrerende direktør i Norges Hovedorganisasjon (NHO), Kristin Skogen Lund (under), og leder i Landsorganisasjonen (LO), Gerd Kristiansen (til høyre).
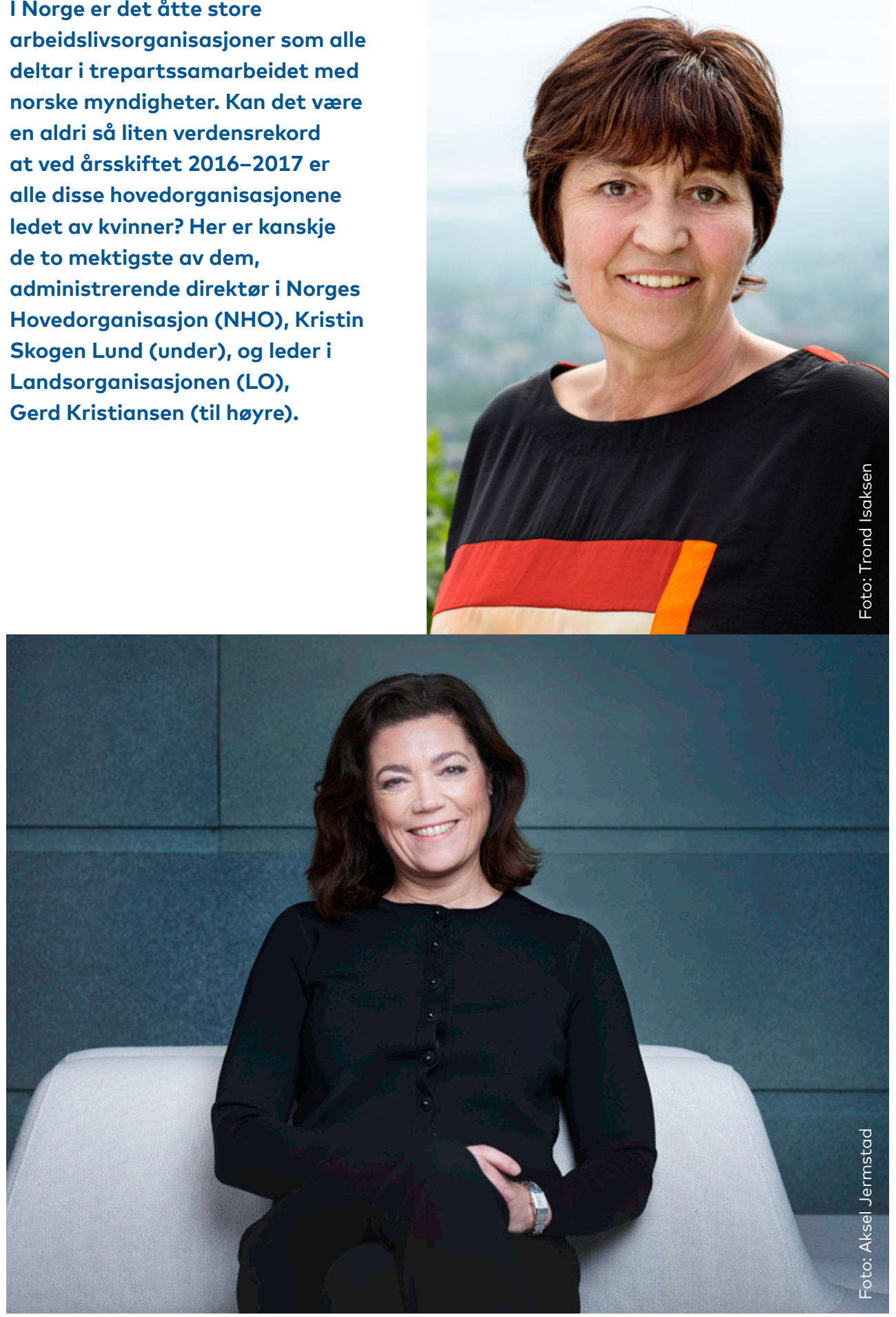


\section{LIKESTILLING I ARBEIDSLIVET}

Deltakelse i arbeidslivet og selvforsørgelse er en forutsetning for likestilling. Likestilling $\mathrm{i}$ arbeidslivet er en egen satsing under Norges formannskap. I 2016 fremmet den norske regjeringen en melding til Stortinget hvor likestilling i arbeidslivet er én av i alt seks hovedprioriteringer. Denne prioriteringen følges opp også på nordisk nivå i 2017. I 2017 er likestilling i arbeidslivet (Women's economic empowerment in the changing world of work) hovedtema for FNs Kvinnekommisjon. I tillegg har de nordiske statsministrene i sitt initiativ fra 2016 pekt på "The Nordic Gender Effect" med fokus på likestilling i arbeidslivet som ett av tre profileringsområder. Målet for statsministerinitiativet er å tilby "nordiske løsninger på globale utfordringer". I arbeidet med en "Gender Effect" kan nordiske løsninger og erfaringer bidra til mulige løsninger $\mathrm{i}$ andre regioner, land eller organisasjoner. Samtidig kan Norden være en tydelig stemme for likestilling internasjonalt.

Norden utmerker seg med at kvinner deltar i arbeidslivet i nesten like stor grad som menn. Samtidig er det flere utfordringer som fortsatt står uløste også på dette området. Å oppnå likestilling i arbeidslivet kan bare skje gjennom langsiktig arbeid. Det vil være avgjørende å involvere partene i arbeidslivet.
Under Norges formannskap har vi valgt å løfte fram to områder hvor vi ønsker økt innsats: vi vil styrke innvandrerkvinners deltakelse i arbeidslivet og bryte kjønnstradisjonelle utdannings- og yrkesvalg. Dette følges opp ved to tiltak:

\section{En egen prioritering innenfor minister-} rådet for likestilling sin støtteordning nordisk likestillingsfond

Det legges som føring at prosjekter knyttet til likestilling i arbeidslivet prioriteres innenfor ministerrådet for likestilling sin støtteordning i 2017. Midlene som NIKK - nordisk informasjon for kunnskap om kjønn, forvalter på vegne av ministerrådet for likestilling skal i hovedsak gå til prosjekter som omhandler likestilt arbeidsliv.

\section{Konferanse: Framtidens arbeidsliv} Norge arrangerer en større, nordisk konferanse om likestilling i arbeidslivet 7.-8. februar 2017 i Oslo, med tittelen Framtidens arbeidsliv. Norges hovedprioriteringer er tema i hver sin sesjon. I tillegg står også likestilling i ledelse på programmet. Konferansen vil avsluttes med en internasjonal sesjon som en del av forberedelsen til FNs Kvinnekommisjon 2017. 


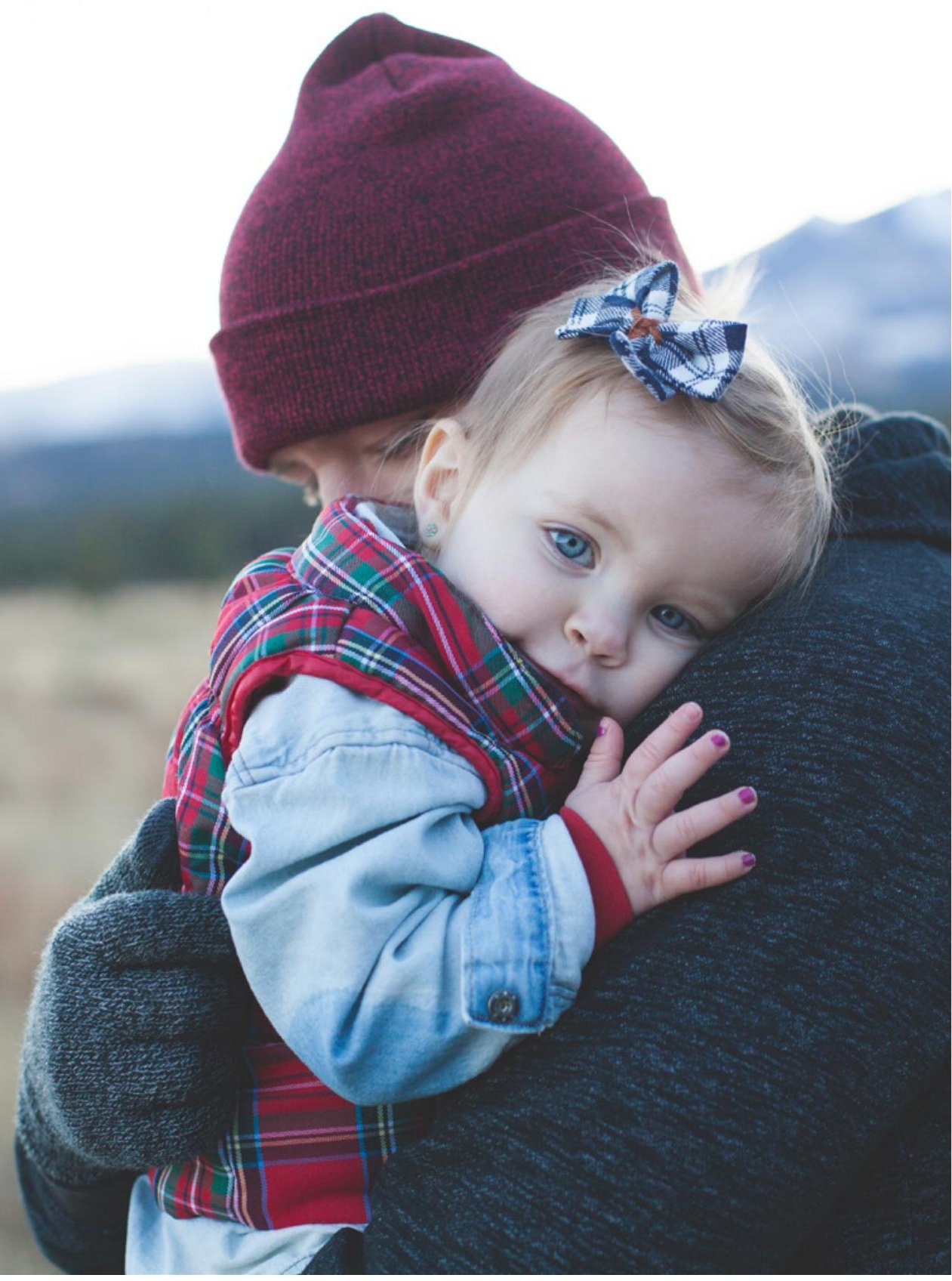




\section{MENN OG LIKESTILLING}

Menn og gutters deltakelse og involvering har vært et særlig kjennetegn ved nordisk likestillingspolitikk de siste tiårene. Dette understrekes også i samarbeidsprogrammet for 2015-2018, Tilsammans för jämställdhet - ett starkare Norden, som rammer inn Norges sektorprogram under formannskapsåret 2017.

I 2017 følger Norge opp vedtaket fra likestillingsministrenes møte 3. oktober 2016, hvor det ble besluttet å arbeide videre med menn og likestilling. Satsingen skal komme innenfor disse tre områdene:

- Menn og helse.

- Menn og utdanning.

- Menn og mannsroller.

Det er et ønske at satsingen særlig skal vektlegge menn og mannsroller.

Island har flere ganger arrangert "Barbershop-konferanser" hvor menn og likestillingsspørsmål har blitt satt på dagsorden. Ministerrådet for likestilling vil derfor i 2017 arrangere én eller flere nordiske barbershopper hvor menn og helse, menn og utdanning og menn og mannsroller, i et nordiskt perspektiv, drøftes. Island vil stå for ministerrådets barbershop-arrangement. 


\section{Andre aktiviteter 2017}

\section{FNs 61. Kvinnekommisjon 2017}

Norden har en sterk stemme i likestillingsdiskusjonen internasjonalt. Det nordiske bidraget for å styrke jenters og kvinners stilling globalt er viktig. I et eget initiativ har statsministrene lansert "nordiske løsninger på globale utfordringer" der høy deltakelse av både kvinner og menn i arbeidslivet står sentralt, kalt The Nordic Gender Effect.

FNs 61. Kvinnekommisjon arrangeres 13. -24. mars 2017 i FNs hovedkvarter i New York. Hovedtema i 2017 vil være "Women's economic empowerment in the changing world of work". Oppfølgingstema er "Challenges and achievements in the implementations of the Millennium Developement Goals for women and girls".

Ministerrådet for likestilling har gitt Norge i oppdrag å sørge for et tydelig Nordisk preg under FNs Kvinnekommisjon 2017. Målet med den nordiske deltagelsen er å utnytte FNs Kvinnekommisjon bedre og mer effektivt for å svare på etterspørselen etter nordiske erfaringer fra likestilling og arbeidsliv og samtidig profilere nordiske løsninger og verdier.

\section{Nordisk-baltisk samarbeid}

Det nordisk-baltiske samarbeidet (NB8-samarbeidet) innen likestillingsområdet bygger på et rammeverk for samarbeid mellom Nordisk ministerråd for likestilling og Estland, Latvia og
Litauen. Dette rammeverket ble vedtatt $i$ et felles ministermøte innen NB8-samarbeidet i 2016. Samarbeidet skal bidra til et sterkere felles samarbeid på likestillingsområdet mellom Norden og Estland, Latvia og Litauen.

Flere av temaene i sektorprogrammet i 2017 vil kunne egne seg for et nordiskbaltisk samarbeid. Fokus for samarbeidet kan forslagsvis konsentrere seg om arbeidet mot hatefulle ytringer.

\section{Den nordiske støtteordningen for likestillingssamarbeid - Nordisk jämställdhetsfond}

NIKK - Nordisk informasjon for kunnskap om kjønn er ministerrådet for likestilling sitt samarbeidsorgan. NIKKs hovedoppgave er, i et nordisk og tverrsektorielt perspektiv, å samle inn og formidle forskning, politikk, kunnskap og praksis på likestillingsområdet. NIKK forvalter også ministerrådet for likestilling sin støtteordning Nordisk Jämställdhetsfond. Dette fondet skal stimulere til samarbeid mellom ulike aktører og organisasjoner på tvers av Norden.

\section{2017 er likestilling i arbeidslivet et} satsingsområde. Det er et mål om at likestillingsfondet skal prioritere prosjektsøknader som er rettet mot arbeidslivet. Norden utmerker seg med at kvinner deltar i arbeidslivet i nesten like stor grad som menn. Samtidig er det flere utfordringer som fortsatt står uløste også på dette området. Å oppnå 
likestilling i arbeidslivet kan bare skje gjennom langsiktig arbeid. Derfor vil det være avgjørende å involvere partene i arbeidslivet.

\section{Nordisk nettverk for likestilling i arbeidslivet}

Under Norges formannskapet i 2012 ble det opprettet et nettverk under embetsmanskomiteen for likestilling for å arbeide med spørsmål om likelønn. I 2014 endret nettverket navn fra Nordisk nettverk for likelønn til Nordisk nettverk for likestilling i arbeidslivet. Nettverket består av representanter fra embetsverkene i de nordiske landene og møtes to ganger per år. I 2016 har nettverket særlig sett på hvordan trepartssamarbeidet bidrar til å styrke eller svekke lønnsforskjellene mellom kvinner og menn.
Norges formannskap foreslår å opprettholde nettverket i 2017. Dette er i tråd med beslutninger i nettverket. Planene for arbeidet i 2017 er blant annet å legge grunnlaget for et nordisk forskningsprosjekt om kvinners yrkesdeltagelse og dens betydning for økonomisk vekst. Et slikt prosjekt kan både ses i sammenheng med landenes rapportering på FNs bærekraftsmål 2030 (mål 5 og mål 8) og Statsministerinitiativet der høy deltakelse av både kvinner og menn i arbeidslivet står sentralt.

Nettverket kan også, på oppfordring fra embetsmannskomiteen, involveres i Finlands fomannskapsprosjekt Norden 2020, som er et samarbeid mellom de fem sektorene arbeid, sosial, likestilling, kultur og utdanning. 


\section{Kalender for formannskapet}

7. februar

Møte i Nordisk nettverk for likestilling i arbeidslivet

7.-8. februar

Framtidens arbeidsliv - nordisk konferanse om likestilling i arbeidslivet i Oslo

\section{8.-9. februar}

Møte i embetsmannskomiteen på Lysebu i Oslo

12. mars

Uformell ministermiddag med eksterne gjester under FNs Kvinnekommisjon i New York

\section{3. mars}

Minister-og ekspertpanel på

FNs Kvinnekommisjon, New York

\section{3. mars}

Women in leadership - nordiskamerikansk debatt hos tenketanken New America under FNs Kvinnekommisjon i New York
8.-9. mai

Ministermøte på Hurtigruten

Svolvær-Tromsø

20.-21. juni

Møte i embetsmannskomiteen

21.-22. juni

Hatefulle ytringer - internasjonal

konferanse i Stavanger

30. oktober-3.november

Nordisk råds sesjon i Helsingfors

\section{Uke $\mathbf{4 5}$}

Møte i Nordisk nettverk for likestilling i arbeidslivet

29.-30. november

Vold mot kvinner og vold i nære relasjoner og Istanbulkonvensjonen - nordisk konferanse i Oslo

\section{Ultimo november}

Møte i embetsmannskomiteen i

København 
$\mathbb{1}$

Nordisk ministerråd

Ved Stranden 18

DK-1061 København K

www.norden.org

ANP 2017:716

ISBN 978-92-893-4880-5 (PRINT)

ISBN 978-92-893-4881-2 (PDF) 